Available online @ https://jiem.jnnce.ac.in

https:www.doi.org/10.37314/JJEM.2020.040209

Indexed in International Scientific Indiexing (ISI)

Impact factor: 1.025 for 2018-19

Published on: 30 March 2020

\title{
Biogas Generation in Single \& Double Digester Kitchen Waste Biogas Plant Using Pongamia Pinnata Seed Cake as Raw Material- A Comparative Study
}

\author{
Chethan S G ${ }^{1 *}$, H B Suresh², M H Moinuddin Khan' \\ 1* Dept. of Chemistry, Jawaharlal Nehru New College of Engineering, Shivamogga \\ ${ }^{2}$ Dept. of Electrical \& Electronics, Jawaharlal Nehru New College of Engineering, Shivamogga \\ chethansgs@jnnce.ac.in, hbs_ee@jnnce.ac.in,drmk@jnnce.ac.in
}

\begin{abstract}
Anaerobic digestion technology has been used since many decades. It is known to be an established technology for biogas generation from various organic matters like cow dung, kitchen waste, fruit waste and municipal wastes. The present work explores the analysis of biogas generation in single \& double digester biogas plant with baffles by using Pongamia Pinnata seed cake as a feed material. The biogas yield has been studied in single \& double digester biogas plant with baffles for a period of 30 days. The yield of biogas in a single \& double digester biogas plant with baffles has been recorded on daily basis by feeding $0.5 \mathrm{~kg}$ and $1.0 \mathrm{~kg}$ of Pongamia Pinnata seed cake. From the experimental results, the average volume of biogas generated is calculated and observed that, in modified double digester biogas plant with baffles, the biogas generated is $57 \%$ more than that of single digester biogas plant.
\end{abstract}

Keywords: Single tank biogas plant, Double tank biogas plant, Pongamia seed cake, biogas generation.

\section{Introduction}

Biomethanation technology has recently become more attractive because of its high performance. Feedstock such as cow dung, human waste, urban solid waste and agricultural residues are used for biogas generation. Biogas generation is a simple type of technology to get energy source from anaerobic digestion of organic matter. The feed raw material Pongamia seed cake is found to be rich in protein, carbohydrate, toxic flavonoids, alkaloids, resin, sugar, and tannins. Pongamia seed cake contains $3.7 \%$ nitrogen, $0.23 \%$ phosphorus and $0.68 \%$ potassium is an excellent organic fertilizer [1]. The feed raw material degrades in three phases for the generation of biogas via anaerobic process, firstly hydrolysis by converting all complex sugars, protein, amino acids \& peptides into simple compounds. Secondly, fermenting bacteria convert simple compounds into acetic acid and phenol. Finally, methane is by the reduction of acetic acid [2]. The biogas generated is composed of $55-65 \%$ of methane $\left(\mathrm{CH}_{4}\right)$ and $30-40 \%$ Carbon dioxide $\left(\mathrm{CO}_{2}\right)$ and other gases like $\mathrm{H}_{2}, \mathrm{H}_{2} \mathrm{~S}$, etc., The calorific value of biogas is found around 5000 to 5500 $\mathrm{Kcal} / \mathrm{Kg}$ [3]. The generation of biogas depends on the composition of raw material feed for digestion. Various biogas digesters are available such as a floating drum type (KVIC model) and fixed domed type (Deenbhandu model). In India, 90\% of the biogas plants were constructed by Deenbhandu model. In 2003, Anand Karve (President ARTI) developed a compact biogas system that uses starchy or sugary feedstock material and the analysis shows that this new system is 20 times more efficient than conventional biogas plants [4]. The production rate of biogas depends on the quality of the substrate, temperature, $\mathrm{pH}$, loading concentration, toxicity, agitation, nutrients, the concentration of residue, construction and size of the digester, the ratio of carbon to nitrogen, retention time, alkalinity, 
initial feeding, total volatile acids, chemical oxygen demand (COD), and total solids (Ts) [4]. The use of slurry from the digester tank can be used as chemical-free fertilizer for crops and it also retains soil fertility [5]. To face the energy crisis and changing climate conditions, the world needs green, secure, carbon-neutral sources of energy. Biogas technology provides sustainable, efficient, and renewable energy through the anaerobic digestion process. The kitchen waste digester plant is the only option for biogas generation with locally available organic resources. The purified $\mathrm{CO}_{2}$ free gas can be used to produce electricity and as a fuel source. Furthermore, the residue left over after the digestion of organic matter is precious organic manure and it sustains soil fertility.

\section{Material and Method}

Two autonomous biogas digester models have been fabricated from commercially available PVC drums for biogas generation. The single tank digester is similar to the ARTI design and it consists of a 750 liter digester tank and 500 liter gas holder tank. The digester tank is connected with an inlet and outlet pipes and enclosed by a floating PVC gas holder tank for gas collection. The gas holder tank moves up's and down depending upon the gas accumulation and discharge (figure 1). The double digester gas plant consists of 1500 liter and 750 liter digester tanks. A baffle is introduced at the center of the 750 liter gas digester tank (figure 2) and a gas holder of 1000 liter tank is placed between 1500 liter and 750 liter digester tank.

After the fabrication of kitchen waste biogas digester plant, the gas plant is filled with innoculum cow-dung and water with the ratio 1:4 and allowed it for stabilization without feeding any organic matter. Once, the biogas starts collecting inside the gas holder, the quality of biogas is tested. The Pongamia Pinnata seed cake is used as feed source for the
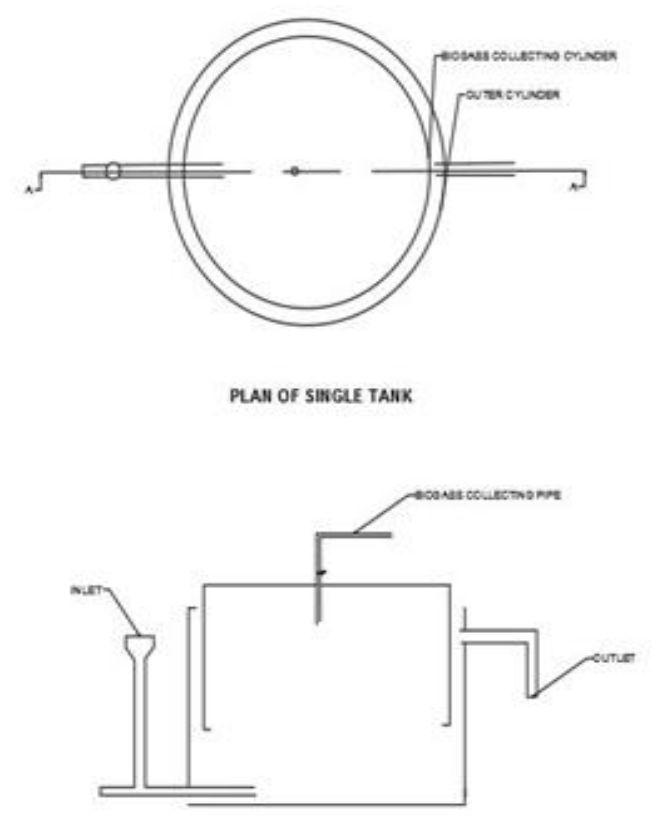

CROSS SECTION QAA

Figure1: Single Tank Biogas Digester

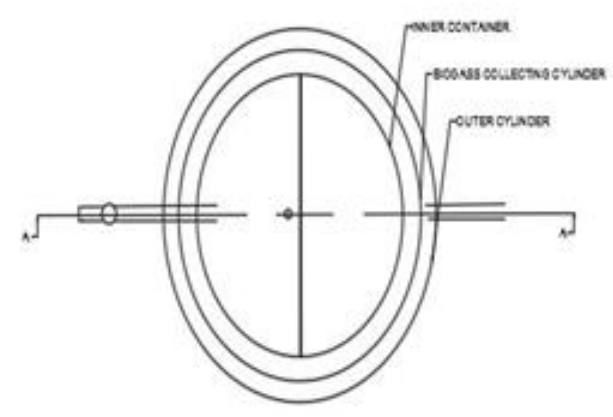

PLAN OF DOUBLE TANK

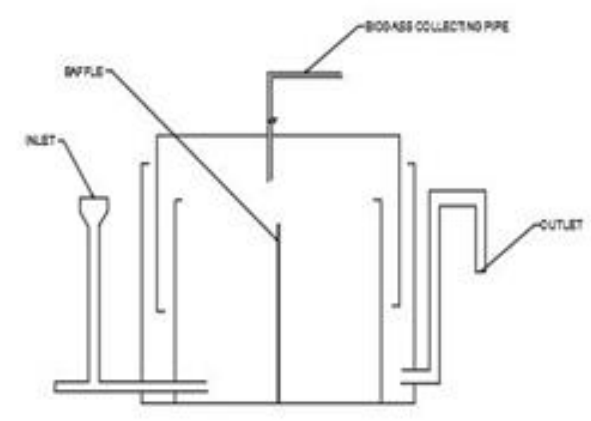

Figure 2: Double Tank Biogas Digester 
fabricated kitchen waste biogas digester plant in the form of slurry. The slurry is prepared by mixing seed cake with water at the ratio of 1:3. This Slurry is fed to digester and it is allowed to decompose for 24 hours. The Biogas collected in the gas holder is measured and recorded daily. For every next feed, the biogas collected in a gas holder is removed off. The biogas generated is measured and recorded every day and this was continued for a period of 15 days with different quantities of 0.5 and $1.0 \mathrm{~kg}$ of Pongamia seed cake in both the single and the double digester gas plants.

\section{Result and Discussion}

The current biogas generation pattern based on the quantity of pongamia pinnata seed cake fed every day into the single \& double digester biogas plant is as shown in the Graph1.It is calculated and recorded by using the equation (1).

Volume of gas $=\frac{\frac{\pi}{4} \times \mathrm{D}^{2} \times \mathrm{h}}{1000}$

Where $\mathrm{D}=$ Circumference $/ 3.142$ $\mathrm{h}=$ Tank height
From figure 3 , it is observed that the average volume of biogas generated by feeding $0.5 \mathrm{~kg}$. of pongamia pinnata seed cake in single digester and double digester kitchen waste biogas plant is 285 liters / day and 454 liters / day respectively. Further is observed that the biogas yield variation in both cases is similar and it stabilizes after ten days.

The average stabilized volume of biogas yield in double digester biogas plant with baffles is 415 liters/day and 242 liters/day in single digester biogas plant.

From figure 4 , it is observed that the average volume of biogas generated by feeding $1.0 \mathrm{~kg}$. of pongamia pinnata seed cake in single digester and double digester kitchen waste biogas plant is 303.0 liters / day and 523.0 liters / day respectively. Further it is observed that the biogas yield variation in both cases is similar and it stabilizes after eleven days.

The average stabilized volume of biogas yield in double digester biogas plant with baffles is 610 liters/day and 342 liters/day in single digester biogas plant.

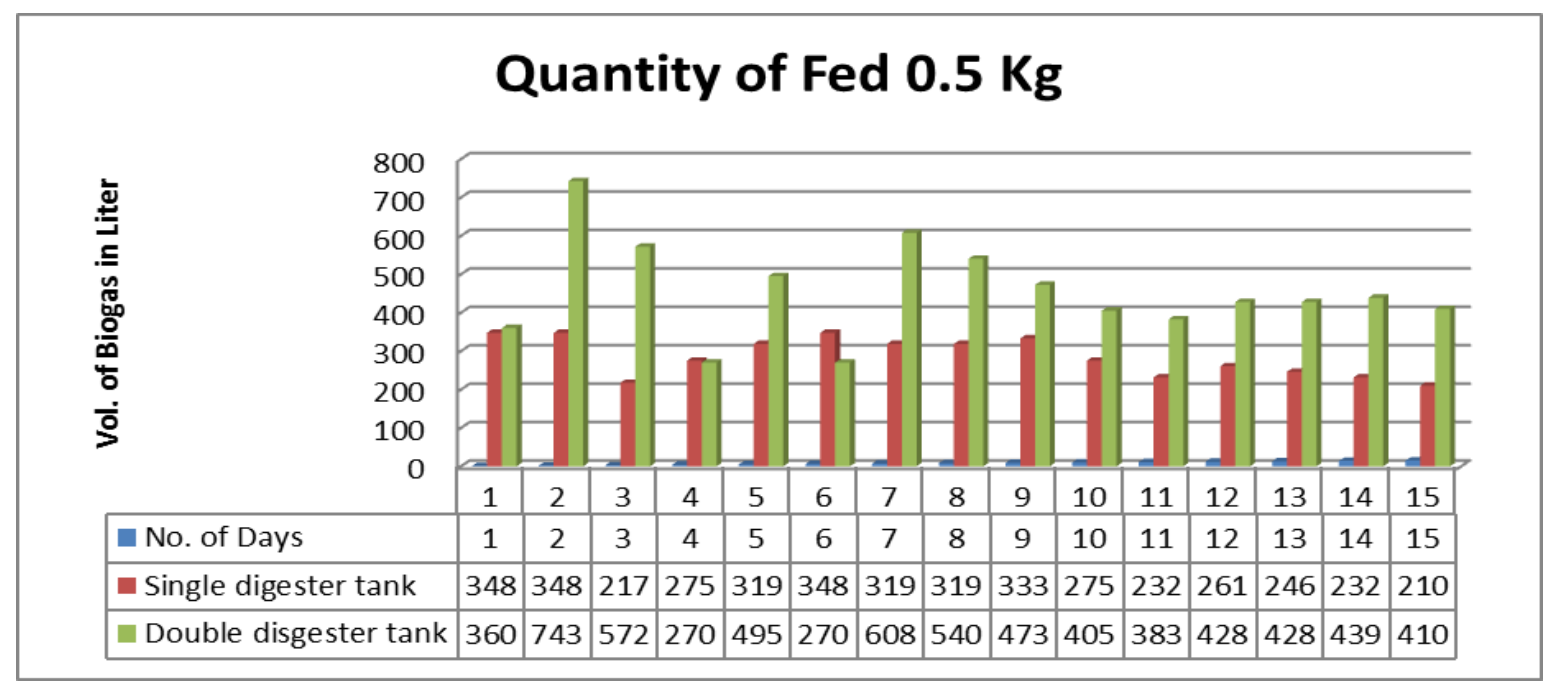

Figure 3: Volume of biogas generated in single \& double digester biogas plant fed with $0.5 \mathrm{Kg}$ of Pongamia Pinnata seed cake 


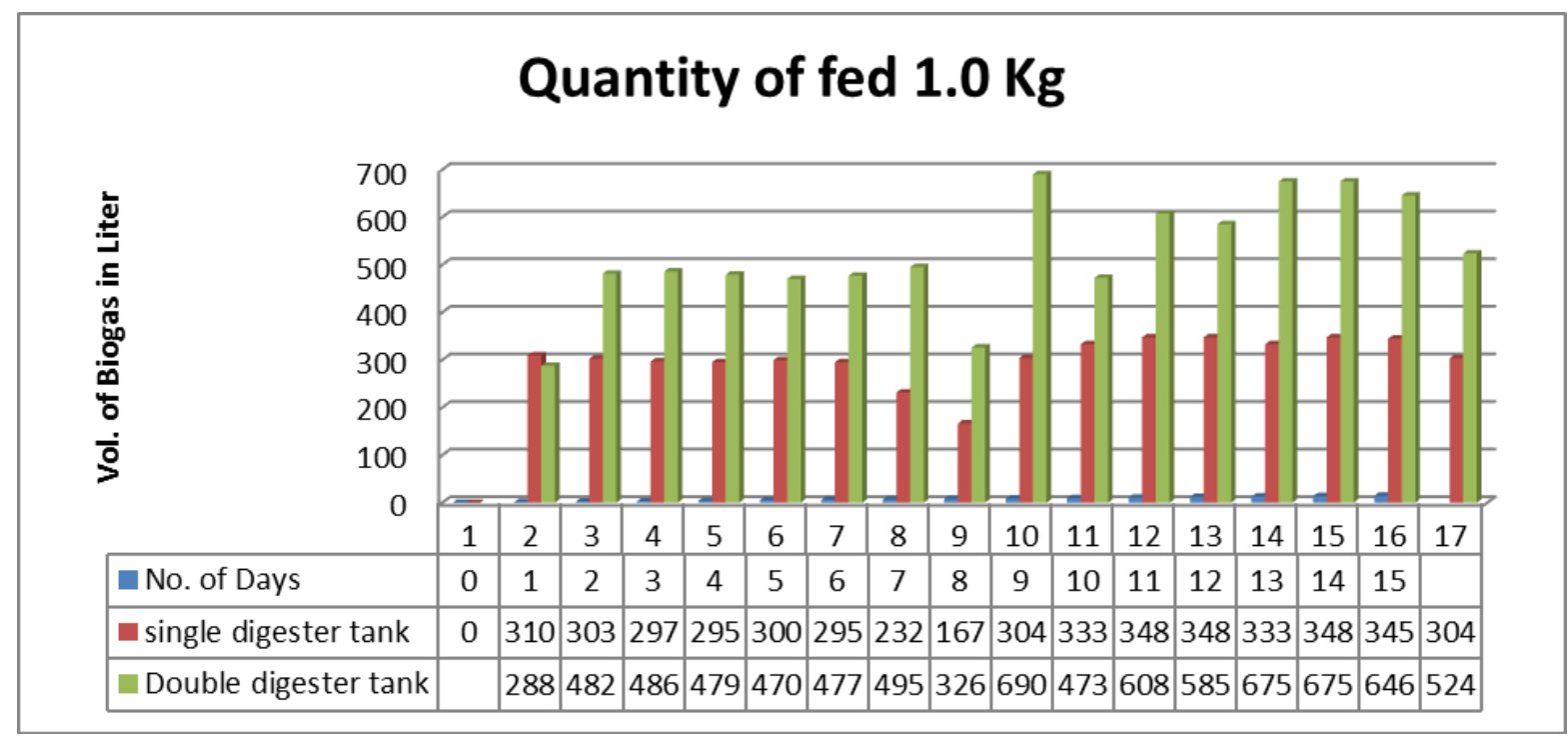

Figure 4: Volume of biogas generated in single \& double digester biogas plant fed with $1.0 \mathrm{Kg}$.of Pongamia Pinnata seed cake

The above experimental results reveals that, for the same quantity of feed material in both digesters (single and double digester), the biogas generated in double digester biogas plant with baffles is more as compared to the single digester biogas plant. In double digester biogas plant with baffle, the organic matter flow from bottom of the digester to its top is guided by the baffles and it requires more time. Since the retention time of the slurry in the digester tank is more and hence the volume of gas generated is more. It is observed that the volume of biogas generated in the double digester biogas plant with baffles is around $57.0 \%$ (after stabilization) more than that of the biogas generated in single digester biogas plant.

\section{Conclusion}

In this work, comparative study on biogas generation in single \& double digester kitchen waste biogas plant using pongamia pinnata seed cake as raw material is explored. First, the single and double digester kitchen waste biogas plant with baffle is fabricated and it is filled with cow dung slurry and allowed it for biogas generation. Further, both the digesters are fed with same quantity (say $0.5 \mathrm{~kg}$.) of seed cake on daily basis for a period of first 15 days and the above procedure is repeated by feeding
$1 \mathrm{~kg}$ of seed cake for the next 15 days and the volume of biogas generated is measured.

The major findings of the work are as follows,

- It is observed that, the average volume of biogas generated by feeding $0.5 \mathrm{~kg}$. of pongamia pinnata seed cake in single digester and double digester kitchen waste biogas plant is 285 liters / day and 454 liters / day respectively.

- The average stabilized volume of biogas yield $(0.5 \mathrm{~kg}$. $)$ in singledigester and double digester biogas plant with baffles is 242 liters/day and 415 liters/day respectively.

- average volume of biogas generated by feeding $1.0 \mathrm{~kg}$. of pongamia pinnata seed cake in single digester and double digester kitchen waste biogas plant is 303.0 liters / day and 523.0 liters / day respectively.

- The average stabilized volume of biogas yield $(1.0 \mathrm{~kg})$ in single digester and double digester biogas plant with baffles is 342 liters/day and 610 liters/day respectively.

- The study reveals that, biogas generated in double digester biogas plant with baffles is $57 \%$ more than that of single digester biogas plant. 
- biogas yield variation in both cases is similar.

- The study is helpful to identify the model of kitchen waste biogas plant suitable for biogas generation.

- It is possible to provide energy security.

\section{References}

[1] K. V. Usharani, D. Naik, and R. L. Manjunatha, Pongamia pinnata (L.): $\quad$ Composition and advantages in agriculture: A review, J. Pharmacogn. Phytochem., Vol. 8, No. 3, 2019, 2181-2187.

[2] Shivani and M. Bashir, Case study of biogas production from various feedstocks. Ecology, Environment and Conservation, Vol.24, No. 4, 2018, 1871-1876.

[3] Bong Su Lim, Byungchul Kim, In Chung Anaerobic, Treatment of Food Waste Leachate for Biogas Production Using a Novel Digestion System, Environmental Engineering Research, Vol.17, No. 1, 2012,41-46.
[4] Karve .A.D, ARTI Biogas Plant: A compact digester for producing biogas from food waste',Available online: http://www.pssurvival.com.

[5] B. Sagagi, B. Garba, and N. Usman, Studies on biogas production from fruits and vegetable waste, Bayero Journal of Pure and Applied Science,Vol. 2, No.1, Jan. 2009, 115118.

[6] Dhanalakshmi Sridevi V. and Ramanujam R. A., Biogas Generation in a Vegetable Waste Anaerobic Digester: An Analytical Approach, Research Journal of Recent Sciences, Vol.1 No.3, Mar. 2012, 41-47.

[7] Sushmita Patidara, Anjani Kumar Dwivedib, "Production and Analysis of Biogas from Municipal Solid Waste," Int. Res. J. Eng. Technol. IRJET, Vol. 7, Issue 2, Feb. 2020, 2466-2473.

[8] M. Krishania, K. Virendra, V. Kumar, K. Anushree, and A. Malik, Opportunities for improvement of process technology for biomethanation processes, Green Process. Synth., Jan. 2012, 49-59.

doi: 10.1515/greenps-2011-0025. 